Mireia Vargas-Urpi*

\title{
Official bilingualism meets de facto multilingualism: public service interpreting for the Chinese in Catalonia
}

https://doi.org/10.1515/ijsl-2018-0003

\begin{abstract}
Catalonia is well known for being a bilingual region with language policies that give full support to promoting Catalan. More recently, the number of languages spoken in Catalonia has risen significantly due to immigration flows, while immigration policies encourage all citizens living in Catalonia to be able to communicate in Catalan with the public Administration. The same immigration policies, however, also acknowledge that interpreting (or intercultural mediation) may be necessary to facilitate immigrants' rights to access public services during the first few years they are living in Catalonia. This article analyses the relationship between a minoritized language (Catalan), a dominant language (Spanish) and a group of recently arrived languages (Standard Chinese and other Chinese varieties) from the perspective of public service interpreting. It discusses some of the results of an empirical qualitative research which included: (a) interviews with public service interpreters and intercultural mediators working with Chinese living in Catalonia, (b) interviews with managers and coordinators in charge of interpreting or mediation services, and (c) questionnaires answered by Chinese users of public services in Catalonia. This research depicts a complex reality: it not only reflects interpreters' and managers' biases towards Spanish or Catalan, often motivated by their place of origin or life experience, but also the challenges when dealing with linguistic variation, i.e. the variety of languages (geolects and mutually unintelligible dialects) included under the umbrella term of Chinese.
\end{abstract}

Keywords: public service interpreting, intercultural mediation, multilingualism, bilingualism, minoritized language

\section{Introduction}

The huge arrival of foreign immigrants since the mid-1990s, particularly during the decade 2000-2010, who did not speak either of the official languages in

*Corresponding author: Mireia Vargas-Urpi, Department of Translation and Language Sciences, Universitat Pompeu Fabra, Roc Boronat, 138, 08018 Barcelona, Spain,

E-mail: mireia.vargas@upf.edu 
Catalonia (Catalan and Spanish) has translated into communication barriers when all these newcomers had to attend public services: when they needed to see a doctor, when they had to register their children for school or when they had to appear in court (either as suspects, victims or witnesses), to name but just a few examples. These problems have been partially addressed in several of the immigration policies adopted by the Generalitat de Catalunya [Catalan Government] in which different kinds of solutions have been suggested to overcome communication barriers. These range from promoting Catalan language courses for newcomers, to the written translation of information (leaflets, websites, etc.), public service interpreting (PSI) - face-to-face or remote - and intercultural mediation (IM).

The Chinese population in Catalonia has increased significantly in the space of only a few years: while in 1998 there were only 2,440 registered Chinese citizens living in Catalonia, in 2009 there were already 45,019; a truly exponential growth in just a decade. ${ }^{1}$ Most Chinese people living in Catalonia can speak Standard Chinese (Putonghua 普通话), also known as Mandarin, but for most of them this is not their mother tongue but a second language acquired through compulsory education in China. In fact, Chinese immigrants' command of Standard Chinese varies according to the length of their education before emigrating from China. ${ }^{2}$

According to Beltrán Antolín (2009: 137) and Masdeu Torruella (2014: 4), around $70 \%$ of the Chinese in Catalonia were born in the Zhejiang province and, more specifically, in the Qingtian district and the Wenzhou prefecture. Although these two areas are close in geographical terms, they are not so in linguistically: in Qingtian and Wenzhou mutually unintelligible dialects from the $\mathrm{Wu}$ geolect (Wuyu 吴语) are spoken. According to Rovira-Esteva (2010: 209), the strong accent and the influence of their mother tongues are clearly evident in their spoken Mandarin. In addition, other dialects are spoken by the Chinese living in Catalonia, such as Hokkien (Fujianhua 福建话) or Shanghainese, to name but just two examples.

Furthermore, Rovira-Esteva (2010: 268) observes two different phenomena among the Chinese families living in Spain. First, couples tend to use Standard Chinese when they come from different regions and do not share a common geolect. Second, some parents decide to speak Standard Chinese to their children when they are born. By doing so, they try to compensate for the lack of access to formal education and linguistic immersion in Standard Chinese. Some

1 Data from Idescat, the Catalan Institute of Statistics. URL: http://www.idescat.cat/

2 For more information about the Chinese in Catalonia, see Beltrán Antolín and Sáiz López (2001), Beltrán Antolín (2009), Masdeu Torruella (2014) and Vargas-Urpi (2012, 2014). 
of the Chinese in Catalonia are learning Catalan (Bové et al. 2008) or Spanish, but adults are usually busy at work and learning the local languages becomes a responsibility that falls to their children, who then take on a further responsibility: that of becoming natural interpreters or mediators for their parents (Beltrán Antolín and Sáiz López 2001: 33).

Against this context, what follows attempts to discuss how the problem of communication barriers with Chinese newcomers has been addressed in Catalonia, a region with two official languages - one of them a minoritized language - and a strong tradition of language planning in recent decades. Section 2 provides a critical overview of language policies within the context of immigration in Catalonia. Section 3 explains the principal data sources for this study, namely qualitative research based on interviews, goes on to compare different perspectives about the relations between the languages focused on here (Catalan, Spanish and Chinese) and addresses the following five questions:

1. How is bilingualism handled by public service interpreters (PSI) and intercultural mediators (IM)?

2. What role do PSIs and IMs play in portraying the image of a bilingual region?

3. How do PSIs deal with Chinese linguistic diversity?

4. What is the position of PSI and IM services coordinators towards the use of Catalan in mediated communication in public services?

5. What is the position of Chinese users of public services towards the use of Catalan?

\section{Language policies and immigration policies}

The sociolinguistic situation in Catalonia is complex, because as often happens in bilingual regions, speakers' language choices are determined by various factors, such as those proposed by Fishman (1965/2000): group membership, situation and topic. A detailed review of bilingualism and language planning in Catalonia goes beyond the scope of this article, but what is relevant for the purposes of this study is that even though both Catalan and Spanish are co-official languages that should be accepted in all the public services - i.e. there is "complete institutional multilingualism with obligatory multidirectional translation in all languages for all" inside Catalonia quoting Meylaerts' (2011: 229) taxonomy - in practice there are clear differences in which language is used.

On the one hand, Catalan is overtly promoted in certain public services such as Catalan schools (cf. Strubell 1996), especially in teacher-student 
interactions. This is directly related to the language-immersion policy that attempts to make learning and using Catalan widespread among students. On the other hand, the use of Spanish prevails in the Catalan legal system; in fact only $12.2 \%$ of court sentences are written in Catalan (Departament de Justícia [Justice Department] 2014), and a recent report has revealed multiple examples of linguistic discrimination towards Catalan in public administration (especially, police and courts) (Ibáñez Ferreté and Torrents Vivó 2016). These differences in the use of Catalan correspond to Diaz Fouces' (2005) description of the characteristics of minoritized languages, where he acknowledges that: "As far as allocation of use is concerned [...] the interference of the dominant languages is very strong. The members of the minoritized linguistic community have to abide by patterns of bilingual behaviour, whereas the members of the dominant community can use their own language in all or most circumstances within the same territory" (Diaz Fouces 2005: 96).

In accordance with the Catalan government's language policies of promotion and standardisation of Catalan, immigration policies in Catalonia also reflect the will to encourage widespread use of Catalan among newcomers. The Citizenship and Immigration Plan 2005-2008 (Generalitat de Catalunya 2006) explicitly included the following objective: "Defensa de la llengua i construcció d'una identitat catalana més forta, més rica i més plural” [defence of the (Catalan) language and construction of a stronger, richer and more diverse Catalan identity] (2006: 40). According to this plan, “Els ciutadans residents a Catalunya, sigui quin sigui llur origen, han de poder comunicar-se entre ells i amb les administracions públiques en català" [all the citizens living in Catalonia, regardless of their origin, must be able to communicate in Catalan with the public Administration] (2006: 41).

At the same time, though, the Citizenship and Immigration Plan 2005-2008 (Generalitat de Catalunya 2006) also acknowledged that professionals capable of "facilitating communication" were needed in public services, especially in those public services where human rights are at risk (e.g. health, education, justice, etc.). The plan advocated using intercultural mediators in healthcare and in prisons, while face-to-face and remote interpreting as well as written translations were put forward as general measures to provide access to other public services (education, social services, housing services, etc.) during the initial period after immigrants arrive in Catalonia.

This was a milestone in the development of services to support mediated communication in Catalonia. The final report about the measures financed by the plan (Generalitat de Catalunya 2010b) confirmed the recruitment of intercultural mediators in city councils and hospitals, the creation of public service interpreting (PSI) services and registers in county councils (consells comarcals), 
a telephone interpreting service for healthcare, ${ }^{3}$ and the translation of leaflets, brochures, videos and websites. The most common languages used for these materials and services were Catalan, Spanish, English, French, Arabic, Standard Chinese (using simplified characters), Urdu, Romanian and Russian.

The plan also supported Catalan courses for newcomers and the creation of tailored materials to promote autonomous learning for specific groups, for instance, the CD "Learning Catalan from Chinese", with bilingual information about Catalonia, Catalan and a section with bilingual dialogues. In fact, promoting Catalan has become a leitmotiv in subsequent plans. According to Climent-Ferrando (2016) "the Catalan politics on language for immigrant integration have strategically built a frame of positive representation and incorporation of immigration to seek the empathy of migrants [into] the Catalan nation-building project." The promotion of Catalan among newcomers is closely related to the Government's own political agenda to strengthen national identity.

The Citizenship and Immigration Plan 2009-2012 also supported the goal of "equity": "el Pla aposta clarament per garantir l'accés normalitzat i en igualtat de condicions de les persones immigrades als serveis públics" [it was firmly committed to ensuring normalised and equal access to public services for immigrants] (2010a: 75), while the Citizenship and Migrations plan: Horizon 2016 (Generalitat de Catalunya 2014) explicitly included the objectives of "[making] the right of access to services universal [sic]" (2014: 77). When they specify the measures they would fund to overcome language barriers in public services, the following are given: linguistic assistance in healthcare, interpreting in police settings (only for foreign detainees) and IM in prisons.

Concerning the justice system, plans only mention police and prisons because court interpreting is already granted by law. Private translation and interpreting companies are selected by the Justice Department in Catalonia on the basis of a public tender and they are responsible for providing interpreters when requested by the different courts in Catalonia. According to the reports of the Justice Department, ${ }^{4}$ Chinese was the sixth most interpreted language in 2011, 2012 and 2013. ${ }^{5}$

Summing up, quoting Ozolins' (2010) terminology, the previous description shows that there is a lack of a "cross-portfolio language policy" concerning

3 According to the report, in 2007, Chinese was the language provided in $39 \%$ of the consultations that requested telephone interpreting.

4 The reports of the Justice Department are made public and available at: http://justicia.gencat. cat/ca/departament/publicacions/llibres_per_tematica/memories/

5 In the report for 2014, only the five most interpreted languages are specified. 
language barriers in Catalonia, and this has led to "sector-specific public policies”, i.e. solutions to overcome communication problems vary among sectors and also among cities or counties.

\section{Method}

This article draws from the data collected for Vargas-Urpi's (2012) dissertation about PSI and IM for the Chinese in Catalonia. This dissertation pursued wider objectives, namely, describing the two emerging professions or eliciting specificities of PSI between Catalan public service providers and Chinese users, among other. However, here the focus is limited to describing how the various languages at play interact in the context of public services.

\subsection{Data collection and analysis}

In-depth interviews were conducted with twenty interpreters or mediators for the Chinese community living in Catalonia and ten coordinators of PSI or IM services; and questionnaires were distributed among Chinese users of public services.

The interviews were conducted between March and December 2010 and they were informal and semi-structured, i.e. even though there was a list of questions and topics to be covered during the interviews, these were not a fixed guide, and could be adapted to interviewees' answers. New questions could be added and the order of questions could be changed if, as interviewers, we felt it could help us obtain additional or relevant information.

Interviews were recorded and transcribed verbatim. These transcriptions were then analysed using Atlas.ti, a program for qualitative data analysis. Qualitative content analysis (Mayring 2000) was used to assign codes and develop a formative analysis (Hertog et al. 2006).

The questionnaires for Chinese users of public services were distributed between October 2009 and March 2010 ${ }^{6}$ and between November 2011 and March 2012. They were written in Chinese and used closed questions (yes/no, multiple choice), as well as open questions where informants could expand on their answers. ${ }^{7}$ Some of the questions included were based on the

\footnotetext{
6 The first period of collection of questionnaires was part of a study developed by the MIRAS research group and funded by the Catalan Agency for Research (2008ARAF100039) (VargasUrpi et al. 2013).

7 The original questionnaire can be consulted in Vargas-Urpi (2012, 2014).
} 
questionnaires used by Valero Garcés and Lazaro Gutiérrez (2008) and Arumí et al. (2011). Sixty-four questionnaires were collected. For answers to closed questions, percentages were calculated, while content analysis was used for open questions.

This multiple data collection provided various perspectives of the same phenomenon, which resulted in a holistic description of PSI and IM for the Chinese in Catalonia.

\subsection{Sample of informants}

The following subsections provide further details and context concerning the questionnaire respondents.

\subsubsection{Public service interpreters and intercultural mediators}

All the interviewees were interpreters or intercultural mediators working in Catalan public services at the time of the interview. Fifteen were women and five were men. This gender distribution is a common scenario in PSI, which has been described as a female-dominated profession (Arumí et al. 2011).

Twelve interviewees were Chinese, seven were European and one was Latin American. Seven of the twelve Chinese interviewees migrated to Catalonia with their parents when they were still children or teens. They came from Zhejiang (4), Fujian (2) and Shanghai (1). The other five Chinese interviewees went to Catalonia to further their studies; they came from Jiangsu (2), Beijing (1), Shandong (1) and Taiwan (1). All the informants had lived in the other country at some point (China or Catalonia), though some longer than others (one year to more than fifteen years). This information already gives us some clues about interviewees' linguistic competence: while interpreters from Zhejiang and Fujian could share their mother tongue (Qingtianese, Wenzhounese or Fujianese languages) with Chinese users of the same origin, the others had to rely on Standard Chinese as a lingua franca to communicate with Chinese users.

\subsubsection{Coordinators of PSI and IM services}

In this sample, informants can be grouped in the following categories:

- Six of them were coordinators of interpreting services in a city council, an association or a trade union. They were in charge of registers of interpreters, some of which were considerably large (INF23's register had more than 120 
interpreters), ${ }^{8}$ while others (those overseen by INF24 and INF25) were very small (no more than ten interpreters).

- Two of them were consultants for citizenship projects in local councils near Barcelona. They were responsible for creating, implementing and supervising IM programmes.

- Two of them were in charge of projects that included training in IM as well as guiding and coaching during the trainees' internship period. They were also in charge of implementing IM services for the organisation where trainees would take their internship.

\subsubsection{Chinese users of public services}

In the sample of Chinese users, $52 \%$ said they were men, $42 \%$ women and $6 \%$ did not give their gender. Although they were asked for their specific place of birth in China, $20 \%$ of the sample simply answered "China”, and $12.5 \%$ did not answer the question. Specific data is therefore only available for two thirds of the sample. Of those surveyed, $28.1 \%$ said they were from Zhejiang province and $18.8 \%$ from Fujian. The remaining informants are from various regions: Liaoning (7.81\%), Guangzhou (3.13\%), Shanghai (3.13\%), Shandong, Sichuan, Tianjin and Taiwan (1.56\% each).

When asked what language they usually speak, they replied as shown in Table $1{ }^{9}$

Table 1: Users' declared native language.

\begin{tabular}{lr}
\hline Language variety & Number of respondents \\
\hline Chinese (no geolect/dialect given) & 29 \\
Standard Chinese or Mandarin & 11 \\
Qingtian dialect & 14 \\
Fujian dialect & 4 \\
Dialect of Zhejiang & 1 \\
Dialect of Changle (Fujian) & 1 \\
Cantonese & 1 \\
No response & 16 \\
\hline
\end{tabular}

8 The abbreviation "INF" followed by a number will be used to refer to interviewees. Informants 1-20 are interpreters and mediators, while 21-30 are coordinators of PSI or IM services. For users, the letter "U" followed by a number will be used.

9 One respondent declared two native languages: Chinese and the dialect of Changle (Fujian). 
The lack of specific answers to this question makes it difficult to have an exact idea of the actual languages spoken by the informants in this third sample. However, based on the information concerning informants' origins, we can deduce that dialects deriving from $\mathrm{Wu}$ - such as Qingtian and Wenzhou dialects - are probably the most common dialects spoken. On the other hand, the lack of answers providing specific dialects - even though this was clearly stated in the question may be related to the Chinese government's language policies, namely a strong promotion of Standard Chinese (Putonghua 普通话) as China's official language.

\section{Analysis: languages in interpreter-mediated communication with Chinese migrant citizens in Catalonia}

The following sections attempt to address the five questions posed in the introduction on the basis of the data collected from the three samples described above.

\subsection{Catalan: challenge or opportunity?}

From a migrant's perspective, a primary consideration when it comes to Catalan is often whether it is worth the effort to learn it, considering that: (a) Spanish can be used in all (or almost all) communicative situations in Catalonia, as often happens in bilingual regions with a dominant and a minoritized language, and (b) Spanish would be more useful if they had to move to other regions in Spain in the future. So to encourage learning Catalan, one needs to appeal to other kinds of motivation such as ideology or identity. This reasoning must be borne in mind when analysing the various positions of the actors involved in PSI for the Chinese in Catalonia.

All the interpreters and mediators interviewed had a good command of Spanish. Interpreters born in Catalonia were bilingual in both official languages, Catalan and Spanish. Among Chinese interpreters who had migrated to Catalonia as teenagers, most could speak Catalan fluently and only two said they felt more confident speaking in Spanish, even though they could understand Catalan perfectly - they had even attended university in Catalan. Their language choice was just a matter of confidence. ${ }^{10}$ One of the latter was

10 It may be interesting to note that they both lived in the metropolitan area of Barcelona. 
informant 7, who mainly worked as an interpreter at schools, and she said that she was aware of the importance of Catalan in education, which was the reason why she was trying to gain confidence in its use. On the other hand, informant 11, whose Catalan had a strong accent from Girona, even hesitated when she was asked which language she considered her mother tongue, finally answering that she considered both Catalan and Chinese as her mother tongues. The informants who migrated to Catalonia as teenagers thanks to the family reunification programme recalled that their learning of the local languages benefited from the smaller number of Chinese immigrants that lived in this region when they arrived (early 2000s), as opposed to some ethnic residential concentration spots that may be detected nowadays.

Chinese interpreters who went to Catalonia to continue their studies already had a good level of Spanish when they arrived, so most had a better command of Spanish which resulted in a much more limited use of Catalan. Non-Chinese interpreters born outside Catalonia were in a similar situation: despite reportedly understanding Catalan, they tended to use Spanish to communicate. Some of them said they were trying to increase their use of Catalan - not all of them, though: informant 18, a Latin American interpreter, said he was not very keen on speaking Catalan, which he regarded as an "imposed" language. None of these informants reported having had any trouble in being hired by associations, city councils or agencies because of a limited proficiency in Catalan.

From the coordinators' point of view, the command of local languages is a deciding factor when employing interpreters and mediators, but the emphasis varies among these groups of informants. In the register coordinated by informant 27 in the Osona county council, a good command of Catalan is the only requirement for being admitted, regardless of candidates' competency in Spanish. When potential candidates cannot speak Catalan, informant 27 encourages them to learn it and to apply again once they have done some basic courses. According to her, interpreters become examples of integration for migrants who may need their services: if they can speak and understand Catalan, they implicitly convey a message of the importance of studying Catalan. This rationale has been incorporated in other PSI services that have been created in the same area.

Informant 23, who also coordinated a county council PSI register, explained that they gave priority to interpreters who could communicate in Catalan, but they also accepted interpreters without Catalan if they had a good level of Spanish and a mother tongue that was not covered in the register. However, they once had the opportunity to open a full-time position for a bilingual employee who could interpret into Arabic, and in the end they could not cover that position because one of the general requirements to be hired by the Administration is to have a C1 level certificate of Catalan. 
Informants 25 and 26 also valued knowledge of Catalan and encouraged interpreters to learn it, but they accepted interpreters without Catalan if their level of Spanish was good. They both felt that Catalan was an important language if interpreters had to work in public services in Catalonia, and it was especially important for interpreters in education (which was the case of the service coordinated by informant 25). On the other hand, informant 22 explained that they always gave priority to interpreters who were also members of the migrated communities; i.e. if they had to choose between a Catalan interpreter who could speak a foreign language, and a foreign interpreter who could speak Spanish, they would choose the latter. According to them, "local interpreters do not work well".

Ninety-five percent of the users surveyed confirmed encountering language barriers when trying to communicate in public services. When asked how they tried to overcome these language barriers, $78 \%$ reported relying on their basic Spanish knowledge, while only a $3 \%$ said they would use Catalan. They even relied more on gestures (34\%) than on Catalan, even though gestures are not universal (Vargas-Urpi 2013). One respondent referred to Catalan in an open question asking for suggestions to improve PSI services in Catalonia. He suggested that "all public service interpreters should know Catalan".

\subsection{Managing Chinese varieties}

Public service interpreting tries to promote communication in participants' mother tongues, or at least that was what some of the coordinators stated in their interviews (e.g. INF27). However, what happens when users' mother tongue is a Chinese variety such as Qingtian or Wenzhou dialects?

Coordinators were not very sensitive to Chinese linguistic diversity. Even though some of them (INF22, INF23, INF27) expressed a preference for Chinese interpreters, none of them said that this was because Chinese interpreters had a better command of a second variety of Chinese, in addition to Standard Chinese. Instead this was motivated by the feeling that interpreters or mediators who had also had the migratory experience would understand users and would better serve as examples of integration and hope to them.

Thirteen of the interpreters and mediators interviewed said that the use of Chinese varieties by users was the main difficulty they encountered in PSI. Of those thirteen, five were non-Chinese and eight were Chinese. It must be noted that, despite users' efforts to speak Mandarin, they may still be difficult to understand because of their mother tongue influence, although informant 3 said she had got used to this Standard Chinese tinged with the accent of certain dialects. 
Using Standard Chinese as a lingua franca was a common strategy in interpreter-mediated interactions if interpreters and users did not share the same mother tongue. However, nine informants recalled meeting users who did not speak Standard Chinese. According to their experience, these situations were rare and the solutions applied were diverse. Five informants presented examples of relay interpreting, where a third person (a user's relative or friend) interpreted from the user's variety into Standard Chinese and vice versa. Other informants mentioned different solutions. In some situations, a very rudimentary Standard Chinese was used, while in others, different linguistic varieties were combined, despite being mutually unintelligible. Informant 7 remembered a situation where a mix of Qingtian and Wenzhou dialects were used: "Entonces ella hacía una mezcla del dialecto de Qingtian con el de Wenzhou y yo tenía que descifrar lo que me estaba diciendo y entonces yo tenía que traducir y esa entrevista fue un poco complicada. [...] Al principio, yo, cogía el mandarín. Pero ya vi que la madre no me entendía y entonces cogí y le hablé el dialecto de Wenzhou" [(The user) was mixing the Qingtian and Wenzhou dialects and I had to decipher what she was saying to me and then translate it. That interview was a bit complicated. (...) At first I tried to speak Standard Chinese, but I saw the mother was not understanding me, so I started using the Wenzhou dialect]. Informant 15 mentioned that she would like to learn some Qingtian dialect to better communicate with many of the Chinese users she had to meet.

Nevertheless, six informants said that Chinese linguistic diversity was not a difficulty they commonly faced because - according to them - most users could speak Standard Chinese. Three informants denied having encountered users who could not speak Mandarin, which contrasts with the examples presented before. One of these was informant 6, who explained that "everybody in China has the obligation of speaking Mandarin", which was the reason why users automatically switched to Mandarin when talking to her, despite the interferences from their mother tongues.

Only $17 \%$ of Chinese users said they had once been assigned an interpreter with whom they did not share the same linguistic variety. This low percentage suggests that this is not a common problem among users. Seven of these respondents also answered the open question related to this issue and provided more information about their personal experience:

- three of them explained that they looked for another interpreter with whom they shared a common language;

- two of them said they continued with the meeting despite the communication barriers, relying on signs and gestures (U13) or using a dictionary (U17); 
- informant U64 explained that he could not finish the procedure he was trying to complete;

- informant U28 explained that the problem was that they relied on a friend's son whose competence in Chinese was limited.

\section{Discussion}

Catalonia, historically a bilingual region, has become a de facto multilingual region if we consider the great linguistic diversity of its population. However, there are clear differences in the use and status of languages. There are two groups of languages: official languages and immigration languages (Turell 2011).

Concerning the official languages in Catalonia, the analysis of the immigration plans described earlier reveals the government's efforts in spreading Catalan among newcomers. In the case of Chinese migrants, there have even been specific training courses and textbooks for Chinese students. However, this has not translated into a wider use of Catalan among Chinese users, at least considering their answers to the question about solutions to overcome language barriers in public services.

There is though, an important exception to this: migrants' sons and daughters who have attended Catalan schools do achieve a fluent level of Catalan, in addition to Spanish, or at least those who arrived in Catalonia with the first migratory flows (which was the case of some of the interpreters and mediators interviewed in the first sample). This confidence in the use of Catalan seems to reflect the success of the linguistic immersion programme promoted in Catalan schools. In contrast, Chinese interpreters who were in Catalonia to pursue higher education and non-Chinese interpreters born outside Catalonia tended to use Spanish to communicate. This language choice reflects the dichotomy between the dominant language, Spanish, and the minoritized language, Catalan. As also shown by Valls (2013) in a documentary, one may "survive” only using Spanish in Catalonia, but not if they only understand or speak Catalan. Catalan speakers tend to automatically switch to Spanish when they feel the other speaker may not feel confident using Catalan, which is the reason why many Spanish-speaking persons do not feel the need to improve or even to learn Catalan.

Some of the coordinators of PSI and IM services are concerned about the minoritized use of Catalan and try to promote it through interpreters and mediators language choices. In county councils, this bias towards Catalan is explicit - and understandable: PSI registers in county councils depend directly on the funding foreseen by immigration plans, where Catalan is also strongly 
promoted. However, in a sample of ten coordinators, only one explicitly mentioned Catalan as a sine qua non condition, and three mentioned Catalan as a desirable skill. The other six coordinators interviewed did not mention Catalan as a requirement when describing their selection processes. These positions reflect that enabling communication is prioritized over language policies in Catalonia, even in government-funded associations and public services (e.g. two of the coordinators interviewed provided IM to public hospitals).

García-Beyaert (2015) distinguishes between language rights and communication rights. After a thorough analysis of the situation in Ontario, the author suggests that "[i]n order to establish effective measures to overcome the barriers to communication posed by language differences, society should see past the identity dimension of language" (García-Beyaert 2015: 210) in other words, providing communication should prevail over language policies (2015: 212). In Catalonia, immigration plans include two distinct goals: on the one hand, to promote Catalan learning among newcomers (a goal that clearly reflects language policies); on the other hand, to develop services to provide effective communication in public services. In this second goal, Catalan is not explicitly mentioned in the plans. This may have given flexibility to stakeholders and resulted in the reality described above: in most situations, both Spanish and Catalan are accepted in PSI or IM services, because what is given priority is the need to communicate - even if this reinforces the hierarchy between the dominant and the minoritized language.

In the second group of languages, the immigration languages, I have focused on Chinese languages. According to Rovira-Esteva (2010: 301), the sociolinguistic situation in China is so complex that simply talking about diglossia or bilingualism is too reductive. Our study seems to show that Standard Chinese acts as a dominant language in interpreter-mediated interactions in public services with the Chinese in Catalonia, and thus users' own varieties become minoritized languages. Here, the dominant language is the language overtly promoted by the Chinese Government's language policies; there have even been slogans that compare speaking Standard Chinese to being civilised. ${ }^{11}$ This bias is reflected in one interpreter's response and to some degree reflected in users' responses when they only acknowledge Chinese as their mother tongue. Furthermore, it is also reflected in PSI and IM services. While some of these services explicitly offer interpreters for certain Arabic varieties (e.g. Moroccan and Egyptian dialects), only Standard Chinese (Mandarin) is mentioned in information leaflets. As a result, when the user and the interpreter or mediator do not share a common variety, the most frequent

11 说普通话, 做文明人 shuo Putonghua, zuo wenming ren. 
solution is just to switch to Standard Chinese. However, the information collected shows some examples of users who did not understand or speak Standard Chinese. Interpreters and mediators tried to overcome this unforeseen linguistic barrier as best as they could, but communication in this kind of situation was still poor and even comparable to communication between providers and users who have a very elementary knowledge of Catalan or Spanish.

Thus, the idea of a de facto diglossia (or polyglossia) in China, as RoviraEsteva (2010: 309) suggests, is supported by the information collected in my study. Migrants who did not attend school in China and who are monolingual because they only speak their local variety (e.g. Qingtian dialect or Wenzhou dialect, in our corpus) are relatively few. Instead, more frequently, users are bilingual and can speak their local varieties as well as Standard Chinese, and would switch between them depending on the situation. Finally, some people are monolingual and only speak Mandarin or Standard Chinese, especially if they come from Northern regions, and this would also apply to some of the children of Chinese migrants raised in Catalonia, as noted by Rovira-Esteva (2010).

Summing up, China's complex sociolinguistic reality is transposed on a small scale to Catalonia. And, again, when language barriers are encountered, communication is given priority, and bilingual users seem to adapt to switching to Standard Chinese if interpreters and mediators do not understand their local variety.

\section{Conclusions}

In Catalonia, the promotion of Catalan is evident in all the immigration plans issued up to date. However, this does not interfere with the development of PSI and IM services to overcome language barriers in order to provide basic communication in public services - they are two independent goals. Some PSI and IM coordinators try to connect these two goals: if interpreters and mediators are migrants who speak Catalan, they become a positive example for their fellow countrymen and women. In general, though, when a candidate has a good command of Spanish, Catalan is not regarded as an essential skill to work as an interpreter or mediator in public services, because the general goal of communication is prioritised.

Immigration policies explicitly recognise Catalonia's linguistic diversity. In this framework, not only are PSI and IM services funded, but also initiatives to make the languages of immigrants visible. In the case of the Chinese in Catalonia, we must refer to a complex sociolinguistic reality that is not always taken into account. Even though there is an increasingly sensitive attitude 
towards Chinese diversity (especially towards the most widely known varieties, such as Cantonese), Standard Chinese seems to be a common lingua franca when PSI or IM services are requested. This may reflect the success of Chinese language policies in the promotion Standard Chinese.

In contrast, Catalan is also the language supported by language policies in Catalonia, but it still plays second fiddle to Spanish in the same kinds of situations. This, again, supports Diaz Fouces' (2005) definition of minoritized language.

In conclusion, this article has tried to put two realities in perspective: bilingualism and multilingualism. It has focused on the examples of PSI and IM for the Chinese in Catalonia based on interviews and questionnaires collected for my dissertation (Vargas-Urpi 2012). In this respect, some limitations must be acknowledged. First, my dissertation focused on the description of PSI and IM as emerging professions, not on a sociolinguistic description of these two practices. For this reason, even though information about language choices and preferences was collected, questions concerning this topic were not systematically addressed. For instance, I did not ask for specific language choices in different public services (e.g. healthcare vs. court). Second, the sample of questionnaires collected from users was relatively small, because it only sought to complement the data collected from interviews. Despite these limitations, this article has connected two fields of research that are usually approached separately language planning and PSI, and it has also pointed to topics that might be further researched in future studies.

Acknowledgements: This article is part of the project funded by the Spanish Ministry of Economy and Competitiveness: "The quality in translation as an element to safeguard procedural guarantees in criminal proceedings: development of resources to help court interpreters of Spanish - Romanian, Arabic, Chinese, French and English" (FFI2014-55029-R). It has also been supported by the AGAUR's recognition of MIRAS research group (2014SGR545).

\section{References}

Arumí, Marta, Anna Gil-Bardají \& Mireia Vargas-Urpi. 2011. Traducció i immigració: La figura de l'intèrpret al serveis públics de Catalunya [Translation and Immigration: Public service interpreters in Catalonia]. Quaderns 18. 199-218. http://www.raco.cat/index.php/ QuadernsTraduccio/article/view/245286 (accessed 23 January 2017).

Beltrán Antolín, Joaquín. 2009. La inmigración china en Cataluña [Chinese immigration in Catalonia]. In Joan Julià-Munné (ed.), Visions de la Xina: Cultura mil·lenària, 125-150. Lleida: Institut d’Estudis Ilerdencs (accessed 23 January 2017). 
Beltrán Antolín, Joaquín \& Amelia Sáiz López. 2001. Els xinesos a Catalunya. Família, educació $i$ integració [The Chinese in Catalonia. Family, education and integration]. Barcelona: Fundació Jaume Bofill, Editorial Altafulla.

Bové, Carme, Noemí Ubach, Paula Ehrenhaus, Laura Estors, Jordi Font, Blanca Guillén, Marta Jarque, Laia Tutusaus, Elisabet alenyà, Maria Fradera, Conxita Navarro \& Laura Corçà. 2008. L'experiència del CPNL amb el col-lectiu de xinesos [The experience of the Language Normalisation Consortium with Chinese students]. Llengua i ús: Revista tècnica de política lingüística 41. 32-41. http://www.raco.cat/index.php/LlenguaUs/article/view/128312/ 177141 (accessed 23 January 2017).

Climent-Ferrando, Vicent. 2016. The European politics on language for immigrant integration: $a$ multilevel comparative perspective. Universitat Pompeu Fabra PhD dissertation. http:// www.tdx.cat/handle/10803/374239 (accessed 23 January 2017).

Departament de Justícia (Justice Department). 2014. Memòria del Departament de Justícia 2014. Generalitat de Catalunya. http://justicia.gencat.cat/web/.content/documents/publica cions/memoria_2014/memoria_justicia_2014.pdf (accessed 23 January 2017).

Díaz Fouces, Oscar. 2005. Translation policy for minority languages in the European Union. Globalisation and resistance. In Albert Branchadell \& Lovell M. West (eds.), Less translated languages, 95-104. Amsterdam \& Philadelphia: John Benjamins.

Ferreté, Ibáñez, Òscar-Adrià \& Eloi Torrents Vivó. 2016. If you address me in Catalan I'll suspend the proceedings. Castrated language rights in Europe. Plataforma per la llengua. https://www.plataforma-llengua.cat/que-fem/estudis-i-publicacions/171/if-you-adressme-in-catalan-ill-suspend-the-proceedings-castrated-language-rights-in-europe (accessed 23 January 2017).

Fishman, Joshua. 1965/2000. Who speaks what language to whom and when?. In Li Wei (ed.), The Bilingualism reader. London \& New York: Routledge.

García-Beyaert, Sofía. 2015. Cross-linguistic communication and public policy: the institutionalization of community interpreting. Universitat Autònoma de Barcelona PhD dissertation. http://www.tdx.cat/handle/10803/383765 (accessed 23 January 2017).

Generalitat de Catalunya. 2006. Pla de ciutadania i immigració 2005-2008 [Citizenship and Immigration Plan 2005-2008]. http://ibdigital.uib.es/greenstone/collect/portal_social/ archives/gencat01/42.dir/gencat0142.pdf (accessed 23 January 2017).

Generalitat de Catalunya. 2010a. Pla de ciutadania i immigració 2009-2012 [Citizenship and Immigration Plan 2009-2012]. http://treballiaferssocials.gencat.cat/web/.content/ 03ambits_tematics/05immigracio_refugi/03politiquesplansactuacio/pla_ciutadania_immmi gracio/pla_ciutadania_immigracio_vcat_2010_06_03.pdf (accessed 23 January 2017).

Generalitat de Catalunya. 2010b. Pla de ciutadania i immigració. Memòria de les actuacions realitzades. http://treballiaferssocials.gencat.cat/web/.content/03ambits_tematics/ 05immigracio_refugi/03politiquesplansactuacio/antecedents/memoria_pla.pdf (accessed 23 January 2017).

Generalitat de Catalunya. 2014. Pla de ciutadania i de les migracions: Horitzó 2016 [Citizenship and Migrations Plan: Horizon 2016]. http://treballiaferssocials.gencat.cat/web/.content/ 03ambits_tematics/05immigracio_refugi/03politiquesplansactuacio/pla_ciutadania_ immmigracio/pcm_2013-2016.pdf (accessed 23 January 2017).

Hertog, Erik, Jan Van Gucht \& Leen de Bontridder. 2006. Musings on methodology. Linguistica Antverpiensia 5. 121-132. https://lans.ua.ac.be/index.php/LANS-TTS/article/view/156/93 (accessed 23 January 2017). 
Masdeu Torruella, Irene. 2014. Mobilities and embodied transnational practices: An ethnography of return(s) and other intersections between China and Spain. Bellaterra: Universitat Autònoma de Barcelona dissertation. http://www.tdx.cat/handle/10803/285193 (accessed 23 January 2017).

Mayring, Philipp. 2000. Qualitative content analysis. Forum Qualitative Sozialforschung/Forum: Qualitative Social Research 1(2). art. 20. http://www.qualitative-research.net/index.php/ fqs/article/view/1089/2386 (accessed 23 January 2017).

Meylaerts, Reine. 2011. Translational Justice in a Multilingual World: An Overview of Translational Regimes. Meta: journal des traducteurs/Meta: Translators' Journal 56(4). 743-757.

Ozolins, Uldis. 2010. Factors that determine the provision of Public Service Interpreting: Comparative perspectives on government motivation and language service implementation. JoSTrans: The Journal of Specialised Translation 14. 194-215. http://www.jostrans. org/issue14/art_ozolins.pdf (accessed 23 January 2017).

Rovira-Esteva, Sara. 2010. Lengua y escritura chinas. Mitos y realidades [Chinese language and writing. Myths and realities]. Barcelona: Edicions Bellaterra.

Strubell, Miquel. 1996. Language planning and Bilingual education in Catalonia. Journal of Multilingual and Multicultural Development 17(2-4). 261-275.

Turell, Teresa. 2011. Llengües oficials i llengües de la immigració: L'equilibri necessari entre els drets lingüístics individuals i territorials [Official languages and immigration languages: The necessary balance between individual and territorial linguistic rights]. In Acadèmia Valenciana de la Llengua (ed.), Actes del I Simposi Internacional sobre Situació $i$ Perspectives del Plurilingüisme a Europa, València 2008, 189-200. València: Publicacions de l'Acadèmia Valenciana de la Llengua.

Valero Garcés, Carmen \& Raquel Lázaro Gutiérrez. 2008. Investigación sobre la calidad de la comunicación en la atención sanitaria a la población inmigrante [Research on the quality of communication in healthcare for migrated population]. In Carmen Valero Garcés (ed.), Investigación y Práctica en Traducción e Interpretación en los Servicios Públicos. Desafíos y Alianzas. Alcalá de Henares: Universidad de Alcalá.

Valls, David (dir.). 2013. Són bojos, aquests catalans!?. Documentary. https://vimeo.com/ 65124539 (accessed 23 January 2017).

Vargas-Urpi, Mireia. 2012. La interpretació als serveis públics i la mediació intercultural amb el col-lectiu xinès a Catalunya [Public service interpreting and intercultural mediation for the Chinese in Catalonia]. PhD dissertation. Universitat Autònoma de Barcelona. http://tdx. cat/handle/10803/96486 (accessed 23 January 2017).

Vargas-Urpi, Mireia. 2013. Coping with nonverbal communication in public service interpreting with Chinese immigrants. Journal of Intercultural Communication Research 42(4). 340-360.

Vargas-Urpi, Mireia. 2014. Public service interpreting for Chinese immigrants in Catalonia: A study based on interpreters', coordinators' and users' views. Language and intercultural communication 14(4). 475-499.

Vargas-Urpi, Mireia, Anna Gil-Bardají \& Marta Arumí. 2013. Inmigrantes en Cataluña: ¿Una comunicación efectiva en los servicios públicos? [Immigrants in Catalonia: Effective communication at public services?]. Hermeneus 15. 291-332. http://recyt.fecyt.es/index.php/ HS/article/view/30301/15898 (accessed 23 January 2017.). 